REPRODUCTION

\title{
Response to: A rational cure for pre-reproductive stress syndrome
}

\section{S Aksoy}

See end of article for

authors' affiliations

J Med Ethics 2004;30:382-383. doi: 10.1136/jme.2003.004770

....................

Correspondence to:

S Aksoy, Harran

University, Faculty of

Medicine, Department of

Medical Ethics and History

of Medicine, Morfoloji

Binasi, 63300 Sanliurfa,

Turkey; saksoy@harran.

edu.tr

Accepted for publication 12 September 2003

This response to "A rational cure for pre-reproductive stress syndrome" first suggests it is existence that is essential and prerequisite to everything good or bad, therefore it deserves to be protected and respected. Secondly, it argues that every life is worth living, even if it is worse than some other lives, if the only alternative is non-existence. Finally, it takes a critical view of and challenges Häyry's suggestion that in a good clinical situation, the idea of the irrationality of having children could be a legitimate part of the guidance given, since it is not the counsellor's or doctor's duty to advise a couple who wish to have children that it is irrational or even immoral to bring a child into life.

$\mathrm{H}$ aving children is the biggest dream of many married couples. However, all couple are not "lucky" enough to fulfil their desire in natural ways. This is where assisted reproductive techniques (ART) help individuals make their dreams come true. It is sometimes the major goal in a couple's life to have children. Empathy for these cases, and understanding their feelings and reasoning is not easy, if not impossible. As a Turkish folk tale goes: A man falls down from a horse and the people around him ask if he wants them to call a physician. He replies, "I do not want a physician, just call me someone who has also fallen down from a horse." Although this is the fact, moral philosophers are obliged to speak a few words about situations in which they have never been. They surely cannot wait to be a handicapped to argue about the "wrongfulness" of their lives. Or, they do not expect to wait until their last years to speculate for or against euthanasia. Therefore, they take the risk of being labelled as "armchair philosopher" and speak out their views in public. Matti Häyry's article "A rational cure for pre-reproductive stress syndrome" can be seen as another example.

Häyry very speculatively examines the morality and rationality of having children. First he defines a set of symptoms, which he later calls "pre-reproductive stress syndrome". This syndrome is characterised by the urge of individuals to have children, a conviction that this urge is self-evidently reasonable, and an illusion that others should help them satisfy it. He says that the syndrome typically disappears, at least for the time being, when the urge is met, and he offers prenatal counselling as standard treatment for this syndrome. There is not much to debate about whether it is possible to call this set of symptoms as a "syndrome", or that these symptoms even exist, since it is not a standard medical term. It is apparent that this expression is Häyry's own invention, to question with a bit of "gentle irony" the assumption that the desire to have children is a healthy trait of human beings.

Häyry states in his article that he is convinced it is irrational and immoral to have children. The main argument of his conviction is that it is immoral and irrational to not avoid suffering while you can. He believes that children may suffer, and it is wrong to bring avoidable suffering into the world. By deliberately having children, parents enable suffering which could have been avoided by reproductive abstinence. However, he fails to realise the irrationality and immorality of the alternative, that is non-existence. As we have argued elsewhere ${ }^{2}$ it is existence that is essential and prerequisite to everything good or bad, and deserves to be protected and respected.

In fact existence is primary. As Spinoza proposed, "No one can desire to be happy, to act well and live well, who does not at the same time desire to be, to act, and to live, that is to say, actually to exist". ${ }^{3}$ It is existence that generates all that is beautiful and perfect, while non-existence cannot produce anything, good or evil. Although existence is entirely valuable in itself, there are degrees of value. I assume that the perfection of an entity's existence is through life. Life is the real basis of existence. Schweitzer argues that the essence of goodness is: preserve life, promote life, help to achieve its highest destiny. ${ }^{4}$ According to him, the fundamental principle of ethics is reverence for life. All the goodness one displays towards a living organism helps it preserve and further its existence, because only living beings can experience their own existence through thinking and reasoning. And all our knowledge is founded on experiences. Therefore it is not reasonable to argue against human reproduction due to the "possibility" of suffering.

Häyry says at least some people believe that they would have been better off had they not been born, therefore they genuinely see their lives as worse than non-existence. However, it is also possible to find plenty of statements against this from people whose lives have been labelled as "wrongful life" or "life not worth living". ${ }^{5}$ Häyry is right in saying human lives can sometimes be bad, but that does not justify claiming it is immoral to take this risk by attempting procreation. Because every life is worth living, even if it is worse than some other lives, if the only alternative is nonexistence.

Abbreviations: ART, assisted reproductive techniques 
McCarthy compares non-existence with being born with an "avoidable" suffering. He says ${ }^{6}$ :

Suppose that a child is born as the result of medically assisted sex selection and has a disease or disability which was caused by the process of sex selection but nevertheless has a life worth living. Had that process not been used, the child would almost certainly not have come into existence at all. It would have been almost certain that either another sperm would have fertilised the egg or the egg would not have been fertilised at all. In either case, the child would not exist. It is therefore implausible that the child has a complaint since it has a life worth living and had sex selection not been used, it would not have existed at all.

Parfit also argues along the same lines in his analogical case $^{7}$ :

A woman can conceive now, in which case the child would have a serious disease, but still have a life worth living, or she can wait two months to conceive, and have a different child with no disease. Many people claim that, in this case, it would be wrong for the woman not to wait. However, we cannot plausibly claim that if the woman does not wait then someone will have been harmed since her child, although diseased, will have a life worth living and the alternative was non-existence.

Many writers, including myself, have claimed that life and existence is always better than non-existence. Therefore, it is irrational and immoral to "sentence" someone to nonexistence while you have the chance to bring them into life and existence. Life may have good and bad days, ups and downs, sufferings and joys-but it is still worth experiencing.

In his "practical" guidelines Häyry suggests, in a good clinical situation, the idea of the irrationality of having children could be a legitimate part of the guidance given. And he goes on to say, "Possible parents could be told that, according to at least one philosopher, it would be all right for them not to reproduce at all". ${ }^{1}$ Counselling techniques and their principles is another subject and too long to be discussed in this commentary, but it is probably not the counsellor's, or a doctor's duty, to advise a couple who wish to have children that it is irrational or even immoral to bring a child into life. This does not serve any purpose but devalues the doctor in their eyes. Can you imagine if you desire something, which is one of the most natural and frequently practised actions in life, and go to someone whom you expect will help you, they try to prove to you how irrational and immoral your desire is. Sometimes it is good to be interestingly wrong rather than being boringly right. But, at least, you must be interesting.

$\mathrm{S}$ Aksoy has a medical degree. After completion of his $\mathrm{PhD}$ in bioethics in the Centre for Social Ethics and Policy at the University of Manchester, UK, he was appointed as Associate Professor and Head of the Department at Harran University, Faculty of Medicine, Department of Medical Ethics and History of Medicine, Sanliurfa, Turkey. He has published papers and made presentations in various topics on bioethics at the national and international levels. He currently edits the Turkiye Klinikleri Journal of Medical Ethics, Law and Medicine and the Journal of International Society of History of Islamic Medicine. He is also vicepresident of the Asian Bioethics Association.

\section{REFERENCES}

1 Häyry M. A rational cure for pre-reproductive stress syndrome. J Med Ethics 2004;30:377-8.

2 Aksoy S. To value life and existence. Eubios J Asian Int Bioethics 1997:7:102-4.

3 Spinoza B. Ethics, trans. In: White WH, Stirling AH. London: Oxford University Press, 1923:196.

4 Schweitzer A. Civilization and Ethics, London: A \&C Black, 1923:26.

5 Davis A. From Where I Sit. London: Triangle, 1989:3.

6 McCarthy D. Why sex selection should be legal. J Med Ethics 2001;27:302-6.

7 Parfit D. Reasons and Persons. Oxford: Oxford University Press, 1984. 